\title{
AFFORDANCES OF RUPTURE AND THEIR ENACTMENT: A FRAMEWORK FOR UNDERSTANDING CHRISTIAN CHANGE
}

\begin{abstract}
This paper moves forward the debate about continuity and rupture in Christian change by approaching it as an empirical rather than theoretical question and interrogating it using a broad comparative method. It argues firstly that different forms of Christianity-Orthodox, Catholic, mainline Protestant and Pentecostal-have cultural logics which offer different affordances of rupture; and secondly that in those cases where Christianity affords rupture, people will perceive this affordance through their own cultural categories and will choose whether and how to enact rupture in a way that is shaped by their existing material circumstances. The approach thus goes beyond currently popular culturalist theorising and seeks to integrate both idealist and materialist perspectives. In so doing it develops an overarching theoretical framework that explains cases of both continuity and rupture and helps to systematically organise the plethora of case studies on Christian change.
\end{abstract}

Keywords: Christianity, Pentecostalism, rupture, continuity, affordance, transformation

\section{INTRODUCTION}

An ongoing discussion within the anthropology of Christianity concerns how the relation between continuity and change when people become Christians should be understood, particularly in reference to the persistence, or not, of traditional cultural forms. Some scholars argue that conversion to Christianity represents a radical rupture and a major 'break with the past' (e.g., Robbins 2007; Meyer 1998a), while others emphasise the significant continuities they see with regard to cultural ideas, categories and concerns (e.g., Hann and Goltz 2010; Hirsch 2008; Scott 2005). New ethnographic cases that support one or other side of the debate continue to be published (e.g., Luehrmann 2010; Schwarz and Dussart 2010; Vilaça 2014), but while these studies often exhibit very sophisticated theorising, there has as yet been no general theoretical framework advanced that can make sense of all of the ethnographic findings and offer an underlying logic to explain why it appears that in some 
cases there is more continuity and, in others, more rupture. This article therefore develops a comparative framework to make sense of the varieties of Christian change.

The starting point for this discussion is the observation that much of the theorising within the anthropology of Christianity has been rather idealist, or culturalist, in nature (Hann 2007; McDougall 2009). This work often starts from a Geertzian position, seeing religion as a cultural system with an internal logic of its own, and then seeks to explore the consequences of this cultural logic in people's lives (e.g., Robbins 2004a), or to show how people initially understand Christian ideas and concepts through their pre-existing cultural logics (e.g., Hirsch 2008; Mosko 2010). In most of these discussions there is very little said about the social, economic and political organisation of people's lives, and how this connects with the particular ideas, symbols and cultural logics they employ. It is as if the material conditions of existence and the cultural system of ideas are considered as largely separate realms and can thus be understood independently of each other. Whilst this approach is in part a reaction against earlier theorising about Christian change that tended to focus overwhelmingly on social and economic factors as driving conversion and almost entirely ignore the content of Christianity as a set of cultural ideas that may have influenced change (e.g., Comaroff and Comaroff 1991; 1997; Green 1995; Lienhardt 1982; see also Robbins 2007), I want to argue that it is time for the pendulum to come back to a more central point where, instead of choosing to focus on either the material or the ideal, we can productively integrate both into a theoretical fr

I believe that such an approach is especially necessary to move forward the debate about Christian rupture and continuity. I argue that the question of how much rupture Christianity brings about is in fact an empirical question rather than a matter of theoretical position. It depends both on the type of Christianity we are talking about, and on the local context and the ways that it shapes the desires and life-projects of socially embedded individuals. It also depends on the way that certain types of change are framed and perceived by the people themselves. Therefore, it is impossible to argue for or against the possibility of rupture, as a theoretical point, by generalising out from one ethnographic case. Instead, an informed comparative approach is necessary that will make it possible to tease out the factors that cause different kinds of rupture or continuity in specific situations (Robbins 2007: 17). Furthermore, this comparative approach needs to be grounded in a theoretical framework that facilitates the integration of both idealist and materialist concerns.

Despite a recent upsurge of interest in anthropological comparison (Gingrich and Fox 2002), there are surprisingly few explicitly comparative studies of Christian groups in different parts of the world. A small number of studies compare different communities within the same ethnic group who convert to different forms of Christianity (e.g., McDougall 2009; Vilaça 2014) and there has been some interest in cross-regional comparisons, particularly between Amazonia and Melanesia (e.g., Robbins, Schieffelin and Vilaça 2014). As yet, however, there has been no attempt to take a salient theoretical debate from within the sub-discipline and seek to address it by using a broad comparative approach. This is all the more surprising since the anthropology of Christianity has been framed from the outset as an inherently comparative endeavour. Comparative studies of Christian groups would appear to avoid many of the dangers of more general comparative work (for example, in 
trying to compare non-comparable categories) and provide a perfect opportunity for systematic analysis of comparable features.

In developing such a comparative framework, I will first draw on the concept of 'affordance', initially developed by the psychologist James Gibson, and more recently utilised in anthropology by Webb Keane (2013; 2014a; 2014b) and Naomi Haynes (2014). In brief, an affordance refers to 'the properties of something in light of what those properties offer to someone who perceives them' (Gibson 1977; quoted in Keane 2014a: S315). Thus, in an oftcited example, a chair affords the possibility of sitting. Whilst Gibson's initial concept was that material objects or environments have affordances, both Keane and Haynes have usefully suggested that anything can have affordances, including for example, cultural ideas. Building on this approach, it has recently been suggested that the comparative study of the ways that people pick up, or disregard, certain Christian affordances could form the basis of an anthropological framework for the comparative study of Christianity (Keane 2013: 13; Robbins, Schieffelin and Vilaça 2014: 561). This paper seeks to develop such an approach and use it to push forward the debate about rupture and continuity in Christian change.

In the first half of this paper I suggest that an important first step in this comparative endeavour is to look at variation in the affordances of rupture offered by different forms of Christianity. Different forms of Christianity-Orthodox, Catholic, Protestant and so on-must be considered as quite distinct cultural systems which offer different possible cultural ideas and institutional forms to those who encounter them. They therefore also offer different affordances of rupture. Understanding the patterns in this variation is thus a necessary first step in building a comparative analysis of rupture and continuity in Christian change.

In the second part of the paper I look at variations in the ways that people try to enact rupture when it is afforded to them. I will focus on the way that the socio-economic environment influences how the various affordances of rupture are perceived and constrain how these affordances of rupture are acted upon. In essence, I look at the affordances of rupture offered by the material conditions in which people live, arguing that while the new cultural ideas offered by some forms of Christianity can encourage rupture by rendering certain new types of behaviour moral, the socio-economic environment may still render these new behaviours unviable. Whilst I am in no way arguing for economic determinism I do believe that the conditions under which people organise their subsistence does indeed place limits on the ideas they entertain and the behaviours that they can take on. And I believe that these more materialist insights need to be brought back into anthropological theorising about Christian change, and indeed about social and cultural change more generally. In doing so it becomes clear that the ability to enact new behaviours afforded by new cultural ideas is limited and shaped by people's socio-economic circumstances, and their ability to change these circumstances. Thus, even when forms of Christianity afford rupture, the way in which people will be able to enact this rupture will vary according to the existing socio-economic situation. Analysis in the second part of this paper thus makes sense of some of the different ways that rupture is enacted in the lives of certain kinds of Christians around the world. ${ }^{1}$

Whereas much of the contemporary anthropological theorising about change, particularly about Christian change, seems to 
imply that there is an infinite degree of variation and possibility and that everything depends on the micro-nuances of the particular situation, in the conclusion I contend that through the plethora of ethnographic cases it is possible to discern pattern and explanatory order. I thus seek to go beyond the culturalist approach that has dominated much of anthropology in recent decades (Kalb 2015: 10) and to move forward the debate about rupture and continuity by using a method that combines materialist and idealist approaches in a broad comparative framework.

\section{VARIATION IN CHRISTIAN AFFORDANCES OF RUPTURE}

The visual psychologist Gibson coined the term 'affordance' to describe what an environment 'offers the animal, what it provides or furnishes, either for good or ill (...) I mean by it something that refers to both the environment and the animal in a way that no existing term does. It implies the complementarity of the animal and the environment' (Gibson 1986: 127). Thus, in the example of the chair, it not only offers the affordance of sitting, but also many other affordances, such as using it as a paperweight or a hat hook or stepladder or for firewood and so on. The affordance perceived depends on the perceiver, and her interests, needs and cultural categories, as much as on the properties of the material object. Thus, a chair does not determine sitting, but it does afford sitting, among several other possibilities.

Gibson's interest was mainly in the affordances offered by material objects, but in extending the concept to use in anthropology Webb Keane suggests:

[W]e might start with the simple observation that not just physical objects but anything that people can experience, such as emotions, cognitive biases, bodily movements, ways of eating, linguistic forms, traditional teachings, or conventional practices possesses an indefinite number of combinations of properties. In any given circumstance, these properties are available for being taken up in some way for some purpose, while others will be ignored. (Keane 2014b: 7)

Naomi Haynes (2014) also suggests that we can apply the concept of affordances to a wider set of issues in seeking to understand 'the difference that Christianity makes' in a more broadly comparative endeavour. This approach, she argues, will help to move the theoretical focus away 'from the individual Christian subject as the primary object of study to explore the social, cultural, and political-economic aspects of Christian adherence' and in doing so will enable us to get closer 'to the way that many Christians experience their religion, namely, as a set of practices and ideas through which to act in and on the world' (Haynes 2014: S364).

Building on these insights I want to suggest that we can use the concept of affordance to re-think the debate about Christian continuity and rupture. I suggest that to understand the various degrees of continuity and rupture that are seen in different empirical cases, an important first step is to consider the different affordances of rupture offered by different types of Christianity. Christianity is not a monolithic thing and generalisations cannot be made based on some kind of Protestant 'ideal type' (see Robbins 2007). The anthropology of Christianity was established as a fundamentally comparative endeavour and the breadth of ethnography now available within the anthropological literature affords the opportunity of a systematic review of how different forms of Christianity drive change 
in different ways. In the following sub-sections I consider each major type of Christianity in turn and show the way that they afford different degrees of continuity and rupture.

\section{ORTHODOX CHRISTIANITY}

Scholars of Orthodox Christianity unanimously argue that its temporality tends to emphasise continuity and does not foreground rupture at all (Hann and Goltz 2010). In line with this, Orthodox Christian practices often show continuity with the pre-Christian past (e.g., Humphrey 2014; Rogers 2010). Orthodoxy thus often encourages, or at least accepts, the inclusion of pre-Christian practices by Orthodox Christians, and quite often is able to include pre-Christian spirits and deities in the pantheon of angels and saints that can mediate access to God. Therefore, it is not surprising that most ethnographic examples of Orthodox Christianity exhibit what its scholars variously call 'hybridity' or 'syncretism'. So, for example, Russian Orthodox Christians in the republic of Marii El continue the pre-Christian tradition of venerating natural objects in sacred sites (Luehrmann 2010), and Greek Orthodox Christians on the island of Naxos stress religious continuity and continue to practice elements of a pre-Christian demonology (Stewart 1991).

In the Gamo Highlands of southwest Ethiopia, where I carried out my own fieldwork, most people had become Ethiopian Orthodox Christians in the early years of the twentieth century following the conquest of the area by the Abyssinian Empire (Freeman 2002b: 33-4). For the most part they continued practicing their traditional rituals and customs and simply added on a thin extra layer of Orthodox Christianity. Thus, when I lived with them in the mid-1990s people might go to church once or twice a year, on a particular saint's day, and possibly refrain from eating animal products on Wednesdays and Fridays and during other fasting periods. When experiencing misfortune, they may pray to Mary as well as seeking to appease the spirits. For the most part, however, their social, economic and political life continued to be organised by the beliefs and practices of the traditional culture which, for example, set the date when people could start ploughing their land, established the rules of exchange between affines and elaborated on ways that agricultural surplus should be transformed into social status by its redistribution in large community feasts (Freeman 2002a). By accommodating traditional beliefs and practices, Orthodox Christianity did not afford any kind of rupture to the people of the Gamo Highlands. As in the examples above, this kind of emphasis on continuity is typical of most kinds of Orthodox Christianity.

\section{CATHOLICISM}

Catholicism also places little emphasis on rupture and is generally accommodating to the inclusion of all kinds of traditional practices and conceptualisations. The anthropological literature is full of examples from around the world in which local Catholics continue with their previous practices in various ways, whilst also taking on Catholic ideas and practices to varying extents (e.g., Cannell 1999; Gow 2006; Madson 2003).

Hirsch, for example, describes how French Roman Catholic missionaries working amongst the Fuyuge of Papua New Guinea in the early twentieth century often looked for parallels between Christian concepts and the local traditional concepts of the Fuyuge. Consequently, they often associated the Christian notion of God with the Fuyuge notion of tidibe, and similarly the Fuyuge themselves would say that two of their tidibe, Hufife and Aling, one male 
and one female, were just other names for Adam and Eve (Hirsch 2008: 146). In seeking these similarities, the emphasis was on continuity rather than rupture, as the missionaries sought to add Christianity to local culture, rather than to replace one with the other. Indeed, Hirsch tell us that today 'virtually all Fuyuge claim to be Catholic (...) but there is little overt evidence of Christianity in their everyday lives' (Hirsch 2008: 155). They continue to practice their elaborate life cycle rituals and ceremonial pig exchanges, whilst at the same time showing great veneration for the Pope.

A somewhat similar situation is found among most Catholic Amerindians in Latin America. Many Amerindians became Catholics in the 1600s following the arrival of Jesuit missionaries and found a way to incorporate Catholic teachings and practices in 'comfortable continuity' with their traditional conceptions (Vilaça and Wright 2009: 13). Thus 'God and Jesus are associated with the pantheon of the traditional spirits, the shamans visit God and talk to him, carved figures of saints are treated as people, redemption depends on actions and the proper observance of rituals, and salvation is understood as a collective act of becoming' (Vilaça and Wright 2009: 3).

More recently, the Catholic approach to traditional cultures has become even more accommodating. From the 1960s onwards, after the Second Vatican Council (1962-65) and particularly after the Second Conference of the Latin American Episcopate in Medellin in 1968, there has been a shift in policy regarding traditional religions and cultures such that it is now believed that Christian 'faith' can only be experienced through particular 'religions' and thus traditional indigenous religions should be actively preserved (Vilaça 2014: S323). From this time onwards, Catholic missionaries have been asked to respect local cultures and to try to uncover the underlying similarities between them and Catholic teachings. Thus, Catholic missionaries working in Latin America since the 1960s have tried to bring Indians to Catholicism whilst nonetheless encouraging the continuation of the traditional rituals and practices (Vilaça 2014: S328). Vilaça, for instance, recalls a Catholic mass which she attended in a village of the Wari' in Brazil in which the priest, after telling the Gospel of the birth of Jesus, asked the Wari' present to tell a similar story from their tradition and was pleased when a man got up and retold a myth about a baby killed by his paternal grandmother (Vilaça 2014: S328). Several other scholars have reported how Catholic missionaries have sought to preserve, or sometimes even reconstruct, traditional Indian cultures by encouraging the building of traditional men's houses or preserving the decorative feather adornments used in traditional rituals (e.g., Jackson 1995:10). As we will see below, these types of behaviour would be quite impossible for those promulgating other more rupture-affording types of Christianity.

It is also noteworthy that Catholics most often speak in terms of continuity between past and present traditions, as described beautifully by Liana Chua of Catholic communities in Malaysian Borneo (Chua 2012). This is also shown in Rebecca Lester's study of Mexican nuns in their first year of training. Even when their religious lives experience a dramatic change, such as that caused by entering the convent, they are encouraged to re-narrate their previous life stories so that the current events appear as a normal continuity rather than as a radical rupture (Lester 2003). Even in the face of significant change, therefore, Catholics seek to find ways to foreground continuity, both with past traditions and past lives and also with the 'one true church'. The Catholic emphasis on continuity should not be seen 
simply as the straightforward reproduction of past tradition, but rather as an explicit form of cultural labour that seeks to find an appropriate balance between sameness and difference (Norget, Napolitano and Mayblin 2017: 5). It is not simply the case that Catholics tend to accommodate traditional practices, but rather that the concept and practice of rupture are not part of the Catholic emic understanding of religious change.

\section{MAINLINE PROTESTANT CHRISTIANITY}

When we turn to look at Protestant forms of Christianity the situation is significantly different. Here ideas of rupture play, or can play, a much more central role. In particular, the insistence on the direct relationship between the individual and God-not mediated by spirits, angels or saints - that is central to the Protestant message, inherently affords the possibility of disentangling people from webs of local social relations. This is so because these webs of social relations are based on series of exchanges that one way or anotherwhether through particular relational forms between kin and affines, through ceremonial pig exchanges or through traditional initiation rites-are generally conceptualised as efforts which seek to appease the spirits. If people can access God, a greater power, directly, then the necessity to appease the spirits, and thus participate in these various social forms, diminishes. However, this affordance of rupture that Protestant Christianity holds is not in any way deterministic. It may or may not be foregrounded by Protestant missionaries and when it is, it may or may not be perceived and acted upon by local people.

In many historical cases the affordance of rupture in Protestant Christianity was not in fact foregrounded by Protestant missionaries, many of whom, like their Catholic counterparts, chose to emphasise continuity over change. This was the case with most of the Protestant missionaries who went to Melanesia in the late 1800s. Anglicans, for example, generally promulgated a missiology of accommodation that encouraged missionaries to build Christian understanding on whatever indigenous beliefs they could interpret as imperfect expressions of Christian truth (Scott 2005: 109). In some cases, the missionaries actually came to admire traditional life and felt reluctant to interfere directly in native customs (Barker 1993: 202). It is thus unsurprising that many of the Anglican Christians in this part of the world emphasise continuity between their traditions and Christianity and, indeed, continue to organise their life broadly on traditional lines (Barker 1992).

Thus, Scott argues that for the Anglican Arosi of the Solomon Islands there has been an accommodation between Christian ideas and traditional ideas such that both can co-exist without threatening each other (Scott 2005). In cases where the ideas do indeed appear to pull in opposite directions, Scott shows how the local people creatively reinterpret Christian elements so that they fit better with traditional social arrangements. For example, the Christian creation story that all people are descended from Adam and Eve has the potential to radically clash with Arosi beliefs that different groups of people are descended from various different mythical entities and therefore now belong to different matrilineages. Challenging these Arosi beliefs would challenge their whole social structure, as the matrilineages play a central role in organising economic and political life as well as kinship. Here, therefore, Protestant theology offered the affordance of rupture. However, the missionaries and the Arosi chose not to act on 
it, and instead they decided to add the different mythical entities and matrilineages into the biblical story and thus found a way to create a hybrid religion that also allowed them to retain their traditional social organisation.

In a similar manner Barker describes the Anglican Maisin of Papua New Guinea, who also became Christians in the early 1900s. The Maisin who live in the villages today continue to rely on subsistence agriculture and traditional systems of exchange and they continue with many of their traditional practices, including elaborate exchanges at birth, adolescence, marriage and death, traditional songs and dances and the telling of myths. At the same time, they have also taken on many Christian elements and 'remodelled them to fit with their own cultural orientations' (Barker 2004: 440). Such a pattern is common across much of Melanesia. It appears that the most salient affordance of Protestant Christianity when it first arrived in the area was not the affordance of rupture with traditional culture, but rather the possibility it offered to end inter-group traditional warfare, and this was something that was highly valued by the local people at the time (Barker 2004: 448).

Methodist missionaries who operated in other parts of Melanesia in the same period placed rather more emphasis on rupture although they also 'did not insist upon a wholesale rejection of all aspects of local culture' (McDougall 2009: 10). They sought instead to encourage people to move away from traditional practices, by promoting practices of 'cooling' ancestral shrines, for example, whereby the men responsible for the shrine would ask permission from the ancestors to cross over to Christianity (McDougall 2009: 11). This was in sharp contrast to the Seventh Day Adventist missionaries in a neighbouring village who, like the Evangelicals discussed in the following sub-section, insisted on a complete break with the past, destroying the traditional ancestral shrines.

Protestant missionaries in other parts of the world placed rather more emphasis on rupture and drew on the theological resources within the Protestant tradition to do so. In many of these situations the local people clearly saw the affordance for rupture and often, although by no means always, chose to act on it. Thus the Comaroffs tell us that when the Tswana of South Africa understood the Christian message of the Protestant missionaries who lived with them in the nineteenth century, they clearly recognised that it was fundamentally antagonistic to their mode of existence and would lead to the disintegration of their rainmaking rituals, initiations and kinship forms (Comaroff and Comaroff 1991: 237-8).The elites thus 'flatly refused to hear the gospel' (ibid.: 238). However, as Joel Robbins tells us in his careful re-reading of the Comaroffs' material, other groups of people, particularly women and marginals, began to engage with the Christian teachings and were among the first converts (Robbins 2007: 8). Viewed from the perspective of considering Protestant Christianity's affordance for rupture, this pattern is not surprising. People in high social positions in the traditional socioeconomic order would not be interested in acting on an affordance of rupture, while those in low social positions would be much more likely to see the potential in this affordance and try to act on it in order to improve their social situation. This is not to say that that is all that they are doing but, at least initially, it is likely to be a significant part of their motivation to engage with and learn about the new set of ideas that is being offered to them. ${ }^{2}$

The German Pietist missionaries of the Norddeautsche Missionsgesellschaft (NMG) who sought to convert the Ewe of Ghana from 
1847 onwards placed even more emphasis on rupture. They foregrounded the importance of breaking with past traditional practices, which they viewed as devil worship and 'fetishism'. As Meyer tells us:

the missionaries preached continuously that by worshipping rivers, stones and other objects, the Ewe were truly worshipping Satan (...) [They] asked the Ewe to burn all objects related to their old religion (...) Converts were no longer to allow 'fetishes' to possess them. (Meyer 1998b: 756-7)

Instead they preached the supreme power of God, the idea of individual salvation, and at the same time they encouraged people to shift from extended family households to smaller nuclear family groupings and from using locally made goods to imported commodities purchased with money. This goes part of the way to explaining why when the Ewe converted to Protestant Christianity they, unlike the Melanesian Protestants discussed above, did not form a hybrid of traditional and Christian forms but instead stopped carrying out their traditional practices and took on new Christian ones. The other factors that are important to understanding the Ewe experience of rupture are discussed below, in the second section of this paper.

This sub-section has shown that while mainline Protestant Christianity affords rupture, it does not necessarily insist on it. Different missionaries in different contexts can choose whether or not to foreground rupture in their approach, thus shaping the way that local people perceive the message of this type of Christianity. In some cases, this type of Christianity can stress continuity and accommodate non-Christian practices, while in other cases the necessity of rupture can be foregrounded and people invited to discard their previous traditions.

\section{EVANGELICAL AND PENTECOSTAL CHRISTIANITY}

The form of Christianity that affords rupture most strongly is Evangelical Protestant Christianity, particularly its Pentecostal and charismatic variants. Whilst there is a huge diversity of beliefs and practices included under this general term, a central feature that they all hold in common is an emphasis on not just the possibility, but the necessity, of rupture-particularly rupture from past beliefs and socio-cultural practices. In the worldview of Evangelical and Pentecostal Christianity all non-Christian spiritual beings are considered to be forms of the devil. Believers must therefore cease any kind of cultural practices that are directed towards these spirits and 'make a complete break with the past' (Meyer 1998a). It is inconceivable that Evangelical or Pentecostal missionaries or teachers would seek to find similarities between Christian and pagan practices or encourage the continuation of traditional practices aimed at appeasing the spirits.

Evangelical and Pentecostal Christians must try to disentangle themselves from extended webs of social, economic and kin relations and seek to become individuals before God. Whilst these ideas can be found in many forms of Protestant Christianity, such as among the German Pietist missionaries to the Ewe discussed above, they tend to be highlighted and foregrounded in a much more uncompromising way in Evangelical and Pentecostal teachings. This type of Christianity has become immensely popular since the 1980s, particularly in Africa, Asia, Oceania and Latin America and is now the fastest growing type of Christianity in the world (Anderson 2004: 1; Freeman 2012: 10); one of the major reasons for its huge popularity is precisely its insistence on rupture. 
Within Evangelical and Pentecostal Christianity ideas about rupture are not just one set of ideas amongst many, they are central and foregrounded. The emphasis on rupture is so clear and so strong that it is one of the first things that potential converts know about this form of Christianity-that it implies and empowers a rupture with past beliefs, cultural practices and social forms. This is so much so that I think it would be very difficult for someone to take on this type of Christianity if they did not actually want rupture in their lives. People who do not want rupture tend to resist this form of Christianity (for an example, see Bacchiddu 2009 on the Apiao of Chile). It is rather the case that people who want to break with the past, who want to take on new social and economic forms, or who otherwise want to change their lives radically are attracted to Evangelical and Pentecostal Christianity precisely because it appears to afford them the possibility of rupture. ${ }^{3}$

In many cases people convert to these forms of Christianity from other more culturally accommodating forms, such as Catholicism or mainline Protestantism, precisely because of the stricter emphasis on rupture that these newer forms provide. In one example amongst many, Canessa (2000) describes the situation among the Aymara Amerindians of Highland Bolivia, who have been Catholics for many generations, forming a hybrid religious life with both traditional and Catholic elements like the Catholic Amerindians discussed above. In the second half of the twentieth century, however, many Aymara, particularly those becoming more involved in market-based economic forms, have converted from Catholicism to Evangelical Christianity. Indeed, they have chosen fundamentalist Evangelical Christianity over other forms of Christianity on offer in the area, including Anglican, Lutheran, Presbyterian,
Baptist or Methodist forms. Canessa tells us that this is precisely because 'Evangelical and fundamentalist churches are much less likely than their co-religionists of the historically more established churches to take an accommodating or relativistic view of what they consider pagan practices' (Canessa 2000: 135). In other words, people choose to join the Evangelical churches precisely because they oppose hybridity and strongly call for rupture.

This pattern is not uncommon in other parts of the world. In much of Melanesia the descendants of those who converted to the culturally accommodating forms of Protestant Christianity discussed above have recently started to embrace stricter Evangelical and Pentecostal forms of Christianity which place a much greater emphasis on rupture (Barker 2012). The pattern is similar throughout much of Africa, where people are now leaving the mainline Protestant churches and joining Pentecostal and charismatic churches in huge numbers (Meyer 2004). In all these places non-Christians are also becoming Evangelicals and Pentecostals with a similar desire to bring about rupture and change their lives. In a way that anthropologists often find uncomfortable, people are choosing to convert to Evangelical and Pentecostal forms of Christianity out of a conscious desire to break free from their traditional cultures. Reasons for this are discussed in the next section.

In summary, we have seen wide variation in the affordances of continuity and rupture offered by different forms of Christianity. In many respects these different forms need to be considered as quite distinct cultural systems, offering their adherents not only different organisational forms, rituals and paraphernalia, but also quite different opportunities for reconfiguring their relationship to traditional spirits and, in turn, to their kin and neighbours. 
While Orthodoxy and Catholicism emphasise continuity, many forms of Protestantism, particularly at the Evangelical and Pentecostal end of the spectrum, foreground rupture and change.

Why these different forms of Christianity differ so greatly with regard to their affordances of rupture or continuity is in itself an interesting question. One view suggests that it relates to the different conceptualisations of transcendence and immanence within the different Christian traditions. Pentecostal ontology holds that there is a morally superior and powerful transcendent realm, quite separate from the mundane realm of daily life, and that occasionally and unexpectedly the transcendent penetrates the mundane world through the Holy Spirit; this in-breaking of spiritual power enables individuals to bring about radical change, such as conversion, breaking with past traditions or cutting relations with kin. Catholic ontology, in contrast, emphasises the immanence of the spiritual in the material world. In this view God's power is constantly present in the mundane world and does not arrive suddenly as a transformative shock. Instead divine change is seen to evolve and unfold gradually over time. These different ontologies of transcendence and immanence can be seen to lie behind the different cultural approaches to rupture and continuity (Robbins 2012). A more materialist view suggests that the difference perhaps relates to the historical relationship that these denominations have had with political authority: Orthodox Christianity has generally been a national religion enmeshed with the state (e.g., in Greece, Syria, Ethiopia, etc.), and the desire to include all peoples within a territory in its fold has perhaps led to its accommodating nature; Catholicism sought to develop one unified structure under the leadership of the Pope in Rome and thus had to acknowledge differences in different territories whilst remaining loyal to one centre; whereas Protestantism, in separating itself from any political authority, came to focus on universal truth that could be exported anywhere but which must be embraced in its entirety (Bialecki 2014). A full discussion of this question is beyond the scope of this paper, but for the argument being presented here it is sufficient to note the ethnographic fact that these different forms of Christianity offer quite different potentials for socio-cultural change.

This, however, is only part of the key to understanding the empirical variation in the degree of rupture or continuity experienced by different communities. When forms of Christianity offer rupture as an affordance, this presents it as a possibility but does not determine whether or not this possibility will be acted upon, and if so, by whom, in what way, or with what consequences. Rather, this is influenced by the perceptions and interests of individuals with particular cultural categories and in specific socio-economic positions and contexts. Furthermore, when people do seek to enact rupture, the way that it plays out will be significantly shaped by existing social and economic factors. The next section therefore examines variations in the enactments of rupture.

\section{VARIATIONS IN THE ENACTMENT OF THE AFFORDANCE OF RUPTURE}

People embrace Evangelical and Pentecostal Christianity because rupture is something that they want. Yet the fact that people embrace this type of Christianity (and some forms of mainline Protestantism), seeking to bring about rupture and to change their lives, does not necessarily mean that they will be able to effect transformation that they desire. This 
form of Christianity offers the affordance of ideational or cultural rupture, but the extent to which people are able to enact this rupture in their lives depends to a very large extent on their social and economic circumstances. Thus, in this second section I consider how the ability to bring about rupture varies in different socioeconomic contexts and according to material factors.

Life is not separated into discrete material and ideal realms; instead, cultural ideas shape the way that social and economic matters are organised and morally evaluated. Furthermore, social and economic factors also place limits on the range of possible cultural ideas. Therefore, change in any aspect of people's lives must somehow or other affect other aspects; a change in ideas, such as the taking on of Christian thinking and values, must in some way intersect with the more material realms of social and economic life. One way in which this intersection occurs is that new cultural notions render some former behaviours immoral and other potential new behaviours moral. In this way these new ideas can both drive and legitimate behaviour change.

Nonetheless, however much these forms of Christianity may afford rupture and behaviour change, the material circumstances in which people live will also influence the extent to which these new behaviours are viable to enact in their day-to-day lives. Consequently, understanding the variety of ways that conversion to Evangelical and Pentecostal Christianity leads to rupture in people's lives requires examination of their socio-economic circumstances and the possibilities for change that are, or are not, afforded by them. I suggest that there are three, broad-brush scenarios: (1) ideational change and socio-economic change take place together; (2) ideational change takes place without socio-economic change; and (3) ideational change takes place in the context of attempted or limited socio-economic change, for example in the case of urbanisation. In these three sets of circumstances the way that Pentecostal rupture is enacted, lived and experienced will be significantly different.

\section{(1) IDEATIONAL CHANGE AND SOCIO-ECONOMIC CHANGE TAKE PLACE TOGETHER}

In this first scenario, where ideational change takes place alongside socio-economic change, radical transformation in the lives of people and communities often takes place. In these situations, people often jettison traditional forms of social and economic organisation and cultural ideas, taking on, at the same time, both new practices and new ideas. The socioeconomic changes open up new possibilities for thought, and the new religious ideas offer ways to make new socio-economic behaviours possible and moral. In this context there is radical rupture.

This is what happened to the Ewe of Ghana, who sought to enact the affordance of rupture that was offered to them by Protestant Christianity in the second half of the nineteenth century. At the same time colonial rulers were also pushing them to make major changes in their mode of livelihood, shifting from subsistence agriculture towards the production of cocoa as a cash crop (Meyer 1998b: 754). The co-occurrence of the possibility for both economic change and religious change intersected to create a pathway of radical change for the Ewe. A group of people, notably not the traditional elite, started to take on Protestant ideas and practices and the affordance of rupture they offered, to 'emphasize individuality at the expense of forms of identity based on lineages or clans and the patterns of production, 
distribution and consumption related to them' (Meyer 1998b: 756). What this meant in practice was that as an increasing number of Ewe engaged in cocoa cultivation and trade they used Protestant ideas and practices to try to disentangle themselves from traditional kin-based webs of exchange and sharing. As Meyer tells us: 'While traditionally, farming was organised by the patrilineal lineages and members were expected to share their wealth with their extended family, the mission emphasized the nuclear family as the unit of production, and distribution and consumption' (Meyer 1998b: 757). Because of this, she notes, 'it was relatively profitable to identify themselves as Christians' (Meyer 1998b: 757). The majority of the Ewe became Protestants at this time, meaning that the introduction of cash cropping for the market economy and the conversion to Protestant Christianity together led to a radical rupture and transformation in the Ewe lived world.

This pattern is very common. Most of the peoples in rural Africa, Latin America or Oceania who have become Pentecostals or embraced other rupture-affording forms of Christianity are those who have experienced profound economic changes and a transformation of their production system towards the production and trade of cash crops, migration for wage labour or jobs in government or business. The Aymara Amerindians of Highland Bolivia, discussed above, provide another example of this confluence of factors. Most of the Aymara who became Pentecostals were those who were living in areas going through profound economic change and who were increasingly engaging in economic forms associated with the market. In the context of opportunities for economic change, it was these Aymara in particular who decided to embrace Pentecostalism. As Canessa tells us, the desire for rupture and the desire for ways to engage profitably in the new economic opportunities that become available are very much connected:

evangelistas (...) provide individuals with an ethic many think more effective in a market economy. Freed from the burdensome obligations of sponsoring fiestas and demanding compadres, evangelistas can accumulate capital and enter into new, more fluid and short-lived, economic relationships (Canessa 2000: 137).

The importance of the possibility for economic change in this type of rupture situation is further highlighted in my own work on the people of the Gamo Highlands of Ethiopia. As mentioned above, most of them had been living according to their traditional religion and practices along with certain elements of Orthodox Christian practice for most of the twentieth century. During the latter part of that century Evangelical missionaries had done their best to convert them to a rupture-affording type of Christianity, but the vast majority of people had steadfastly resisted these attempts and rejected this Christian form (Freeman 2013b). However, at the turn of the century, when faced with the possibility of major economic change through a new NGO development project, they became much more interested in this ruptureaffording type of Christianity.

The NGO development project started in 1998 and afforded people the possibility of socio-economic change by showing them how to grow and sell apples as a cash crop. This initiative turned out to be very successful and many people started to make a lot of money. Up until this point most people's lives were organised according to the traditional Gamo culture. At the centre of this culture were the halak'a initiations, essentially a form of 
'redistributive feasting' whereby men sought to amass surplus wealth in order to take prestigious titles by sponsoring huge feasts feeding the whole community (Freeman 2002a; Halperin and Olmstead 1976). Through these balak'a initiations, wealth was circulated and redistributed in specific ways throughout the community to ensure that fertility, wellbeing and ongoing wealth was bestowed by the spirits. At the same time, they ensured that no one was able to accumulate too much wealth, as those with a surplus were always asked to become balak'a. During my first period of fieldwork in the mid-1990s people were becoming halak'a in large numbers and I spent much of my time at the initiation feasts.

However, once people started to make money from growing and selling apples in the early 2000s they also began to see the potential benefits of disentangling themselves from these traditional exchange networks. Faced with the decision to either plough their profits back into the traditional system or to keep them for themselves and invest them in their families and their businesses, many found that they wanted the latter. Within the traditional culture this was not an option; there was no morally legitimate way to refuse when the elders asked you to get initiated. However, within the Pentecostal worldview, refusing to partake in these practices, now seen as forms of devil worship, was absolutely moral. Hence, the Evangelical-Pentecostal affordance of rupture rendered desired new behaviours moral. This was one of the major reasons that it suddenly became attractive.

When I returned to the highlands in 2003 and $2004 \mathrm{I}$ heard people saying things like 'the traditional system [dere woga] makes you poor. It is better to be Pente.' After decades of resisting Evangelical-Pentecostal Christianity, people suddenly started to convert in huge numbers. In a few short years the majority of the Gamo people stopped their traditional practices and took on Pentecostalism (Freeman 2012b; 2013a). They ceased carrying out the balak'a initiations and all other traditional rituals associated with the spirits (including all ritual practices connected to agriculture and fertility) and shifted the focus of their ritual and communal life to the church. When I last visited in 2010 the apple business was booming and many people were doing well economically. They were thus finding it possible to disentangle themselves from the ties of kin and community to a large degree, and the processes of exchange and redistribution that existed into the 1990s have now come to an end. In the past twenty years they have experienced a major rupture: in their cultural ideas, in their mode of subsistence and in the very fabric of their sociality (Freeman 2015).

Furthermore, most people who take on a rupture-affording type of Christianity at a time where major economic change is either an actuality or a possibility generally succeed in building a new, fairly coherent lifestyle where they stop carrying out aspects of their traditional culture that link to socio-economic matters and take on Christian cultural ideas and market-driven socio-economic forms.

\section{(2) IDEATIONAL CHANGE TAKES PLACE WITHOUT SOCIO- ECONOMIC CHANGE}

In certain circumstances, however, people desire rupture and embrace Evangelical or Pentecostal Christianity hoping that it will help them transform their lives, but then find that they have no way to transform their economic arrangements and modes of subsistence. In this situation the conversion to these ruptureaffording types of Christianity is unlikely to 
be stable, as there will be a clash between their cultural systems and the material realities of their day-to-day lives. In this type of situation what often happens is that people give up Pentecostalism and revert to their previous cultural ideas and practices. Vilaça tells us, for example, that while some Wari' Amerindians of Brazil became Catholics, as discussed above, other villages were missionised by Evangelical missionaries and converted to Evangelicalism en masse around 1970, stopping their traditional practices. In the Wari' understanding of the Christian message that all people are equal and are children of God, this meant that kin and affines would not be different and thus the danger of sorcery and attack from affines would be mitigated. However, since there was little opportunity for social or economic change, affines continued to act as they always had; people found that Christianity could not protect them from sorcery attack and that their traditional practices were necessary to resolve these situations. Thus a few years later they relapsed into their traditional practices. Sometime later they tried again to live as Evangelical Christians, but relapsed once more a few years later. For some thirty years they oscillated back and forth, with Christian and traditional animist periods, unable to form a stable Christian life while living as hunterhorticulturalists in the Brazilian Amazon (Vilaça 2014: S326).

Whilst this kind of oscillation back and forth between Christian and traditional periods is fairly common in this type of situation, there are also other possibilities. In some cases, people take on the new cultural ideas of Pentecostal Christianity and then live, at least for a period, in a situation of 'moral torment' as they experience the constant clash of their new cultural ideas with their unchanged socioeconomic realities. Such a situation has been described in sophisticated detail by Joel Robbins' in his discussion of the Urapmin of Papua New Guinea, who en masse converted to Pentecostal Christianity in 1977 (Robbins 2004a). The Urapmin longed for economic change. They had seen plantations in other parts of Papua New Guinea and some of the men had travelled to work on them for a few years; they watched as mines were developed in neighbouring communities and people got money and jobs; they saw small towns being built in other communities and watched as people started to purchase Western commodities (Robbins 2004a: 100-102). Yet this kind of change did not come to their remote village. Instead they continued practicing their traditional small-scale swidden agriculture, while at the same time abandoning almost all the traditional cultural practices that used to organise and regulate it. Robbins describes the clash of values-witnessed when carrying out fieldwork - that the Urapmin were experiencing between the relational values of the traditional culture and the individualist values of Christianity, concluding that they would be unable to overcome this value clash while they continued to practice traditional subsistence agriculture on land held by kin groups. One wonders how long the Urapmin will be able to live with this ongoing moral torment. It is tempting to see it as a transitional phase and to assume that at some point they will surely find a way to bring more coherence into their lives, whether by finding a way to change their economic livelihoods-perhaps by migrating for work in mines or plantations or by finding a cash crop that they can grow and sell-or by creatively moulding a form of Christianity that will allow some aspects of traditional practice, or by some combination of the two.

The Urapmin case highlights the general point that it is difficult to live as a Christian 'individual' in a traditional, non-market economy. 
This is a point that comes out in many ethnographies of Christianity. Where traditional modes of subsistence serve to tie people together in various kinds of exchange and redistributive relations, it is extremely difficult to take on a moral ethic that centres around the individual.

\section{(3) IDEATIONAL CHANGE IN} THE CONTEXT OF ATTEMPTED OR LIMITED SOCIO-ECONOMIC CHANGE, SUCH AS URBANISATION

This takes us to the third scenario, wherein there is only a limited degree of economic change or economic change is something that is being attempted but not fully realised. Particularly since the 1980s, many peoples in Africa, Oceania and Latin America have been struggling to make economic changes in a difficult environment. In this type of situation people still seek to disentangle themselves from social ties, while knowing that they can never fully do so. During periods of economic struggle, creating economic individualism-or at least a focus on the nuclear family-is an ongoing process that can only be sought but never fully attained. In this situation one of the most popular forms of Christianity is neoPentecostalism, or third-wave Pentecostalism. In this form of Christianity rupture is seen as a process rather than an event and pastors emphasise the ongoing nature of the battle against the spirits and their associated traditional forms. The spirits of the traditional culture are re-framed as the devil and life is seen as a constant battle of God against the devil, or good against evil. In this way a rather different type of syncretism or hybridity takes place. Whilst local spirits and traditions continue to exist and to be valued in non-rupture-affording Christianities, in neo-Pentecostal contexts the continuing existence of the spirits is acknowledged but completely re-valued to the effect that what were often creative forces are now considered the devil (Robbins 2011). In this form of Christianity there is an emphasis on 'spiritual warfare' and rituals of exorcism and deliverance as people struggle with their social and economic entanglements, constantly trying to release themselves but at the same time fearful of becoming totally free.

An example of people taking on this type of Christianity during a time of economic struggle can be found in the later experiences of the Ewe of Ghana whom we have met above. From the 1940s onwards, their economic condition began to worsen. The cocoa trade declined due to decreasing world demand and in the 1950s cocoa production ceased altogether in Peki, where Meyer did her fieldwork, due to the outbreak of a devastating cocoa disease that ruined the crop. There was no alternative cash crop available and people either had to return to subsistence production or migrate in search of wage labour. Their economic situation significantly worsened and many were plunged into poverty. People again began to rely on extended kin and to value the kind of social and economic entanglements in which people helped each other (Meyer 1998b: 758). In this changed economic context, people started to leave the mainline Protestant church and join newly emerging neo-Pentecostal churches which focussed on demonology and the continual re-enactment of rupture. Meyer tells us that in contrast to the mission churches they find it important to keep on fighting Satan' (Meyer 1998b: 761). In this form of Christianity there is an emphasis on 'spiritual warfare' and rituals of exorcism and deliverance, where 'deliverance is to ensure that a person is severed from all previous ties with spiritual entities, as well as from the social relations they imply' (Meyer 1998b: 761-2). 
Perhaps the most typical occurrence of this type of situation is when people migrate from the countryside to towns. Newly detached from their kin group, land and traditional way of life, urban migrants strive to forge a new life based on urban norms, individualism and a market economy. Yet for the vast majority this is a constant struggle. They seek to detach themselves from the economic obligations of the village, with its demands for sharing, redistribution and/or participation in expensive rituals, so that they can become economic individuals and accumulate capital for their own use, but, on the other hand, they need to conserve, or build, forms of social and economic ties as insurance against the hard times that they are only too aware that they may experience (Haynes 2012; Meyer 1998b). Thus, rupture can never be complete in these cases, and we see that churches offering deliverance rituals that enact rupture again and again and again are extremely popular in many urban settings throughout much of the Global South. ${ }^{4}$

This theme is so prevalent in urban centres that it has become the central trope for many popular Pentecostal films and teleserials (Meyer 2003; Pype 2012). These films 'thrive on a moral geography that opposes the village, which is the realm of the extended family, and the forces of nature, on the one hand, and the secluded house in the city, on the other' (Meyer 2003: 212). Protagonists are seen struggling to disengage themselves from occult traditional practices and distant village kin by engaging in exorcisms and other deliverance rituals. The desired outcome is to live a good Christian life as a nuclear family in a nice house, but the constant intrusion of evil spirits and the ongoing demands for connection from kin and neighbours makes attaining this goal impossible.

African Initiated Churches (AICs) are also popular in these situations in many African towns. Whilst these churches often look very different to neo-Pentecostal churches, with priests wearing white gowns rather than Western suits, they too seek to help followers go through an ongoing process of breaking with the past and bringing about rupture in their lives. In his classic studies of South African Zionist churches, Sundkler argues for the centrality of the process of rupture in these churches (Sundkler 1976: 305); more recently Engelke tells us that, like Pentecostals, followers of the Masowe church in Zimbabwe, 'also want to break with the past' and that 'breaking with the past is a long-term project in which certain aspects of what get defined as African culture and an African world-view are purged from one's life' (Engelke 2010: 181). In a process that parallels Pentecostal deliverance, members of the Masowe church strive to follow 'mutemo'-the religious law-in order to separate themselves gradually from entanglements with kin and ancestors. For followers of these churches, as with the neo-Pentecostals, rupture is seen as an ongoing process that must be worked on and struggled with over time.

\section{CONCLUSION}

In this paper I have embraced Joel Robbins' argument that we must look at the cultural logic of Christianity itself when considering Christian change, while I have also expanded his perspective from simply considering an ideal type' of Protestant Christianity to comparatively examining the different cultural logics of different types of Christianity (Robbins 2007). In this way I have shown that different forms of Christianity-Orthodox, Catholic, Protestant, Pentecostal and so on-afford different degrees of rupture. I have also argued that this goes a long way towards providing understanding of the empirically different situations of 
rupture and continuity that can be found in the ethnographic record. I believe that it is no coincidence that most of the scholars on the 'continuity' side of the rupture/continuity debate study peoples who have embraced non-ruptureaffording forms of Christianity (e.g., Hann studied Orthodox Christians, Hirsch studied Catholics, Barker and Scott studied Anglicans), while most of those on the 'rupture' side studied rupture-affording types of Christianity (e.g., Robbins and Meyer studied Pentecostals).

I have further sought to move the debate forward by arguing that while certain types of Christianity may afford radical rupture, how this is perceived and how this is acted upon is a facet of specific local conditions, including preexisting cultural logics and social and economic circumstances. Therefore, it is important to look at both the Christian affordance of rupture and the possibilities of its enactment. I have shown that the possibility of enacting radical rupture is to a very significant extent constrained by the existing socio-economic conditions and the possibility of changing these conditions; I have further argued that the consequences of the ideational rupture of certain forms of Christianity will thus vary in different socioeconomic contexts in fairly predictable ways.

Viewed from this perspective, I believe that it is possible to suggest that there is a pattern to the way that communities change when they embrace Christianity, and likewise a pattern in the degree of continuity or rupture that they experience. In broad-brush terms it is possible to argue that:

1. Conversion to forms of Christianity that do not afford much rupture (Orthodox, Catholic, some mainline Protestant) will lead to hybrid cultural forms and will be popular in circumstances where there are only limited possibilities of socio-economic change. When these types of Christianity are attractive to people it is because of other affordances (e.g., for identity, or community, or the ending of tribal warfare, etc.).

2. Conversion to forms of Christianity that afford radical rupture (Evangelical and Pentecostal Christianity, and some forms of mainline Protestantism) will entail a more radical ideational break and there will be far less, if any, hybridisation or syncretism. Conversion to these types of Christianity will be popular in circumstances where people desire socioeconomic change or are already experiencing socio-economic change.

a-When people are able to achieve significant socio-economic change, as well as Christian conversion, the new Christian ideas will render the socio-economic changes moral and the new behaviours afforded will be seen as ethical and appropriate. The resulting new Christian culture will be fairly stable.

$\mathrm{b}$-When people convert to a ruptureaffording form of Christianity and do not make changes to their socio-economic organisation, they will face a clash between their new cultural ideas and their material reality. This will either lead to de-conversion and a reversion to preexisting cultural ideas and practices, or to a very unstable transitory situation in which people experience moral torment and/or frustration at the inconsistencies in their lives before finding some kind of resolution.

c-In situations of intermediate or attempted socio-economic change, or when people are struggling to survive in a challenging new economic environmentfor example, when moving between rural communities and urban settings-people 
are most likely to choose a form of Christianity which enacts rupture as an on-going process.

3. When people are able to achieve socioeconomic change, and are faced with a variety of Christian possibilities, they will most likely choose rupture-affording types of Christianity over non-rupture-affording types.

This framework is offered as a rough guide to making sense of the varieties of Christian change, and the associated variations in continuity and rupture, which are experienced by different communities. Whilst there will no doubt be cases that do not fit this framework, due to an unusual constellation of local factors, I believe that it can nonetheless help to bring some order to the huge empirical variation that has become evident from the growing number of ethnographic studies of Christian communities around the world. Whilst a comparative approach such as this will necessarily gloss over many of the nuances of specific ethnographic cases, it has the benefit of allowing a macro-scale view of general processes that cannot be seen in any one small-scale study. In this way I believe that the model can help scholars to understand the dynamics of Christian change, and indeed socio-cultural change more generally, and that it provides a valuable and necessary contribution to the debate about Christian continuity and rupture.

\section{NOTES}

1 In the view that I am presenting it is possible for either the material or the ideational to be the primary driver of change. Thus, in some cases Christianity may cause rupture, while in others it may merely reflect or refract a pre-existing social or economic rupture. Either way, once one part of the system starts to change the other will necessarily be affected. This is not to say that 'cultures' must be integrated into coherent wholes, or that the material and the ideal are interlinked in some mechanistic kind of way; rather it acknowledges that everything is connected in a kind of fuzzy system and that once one part starts to move other parts will be pushed to move also.

2 Whilst my analysis takes material factors seriously, it should be noted that it is significantly different from the analysis of the Comaroffs, which Robbins has criticised as focussing only on socio-economic form while ignoring the cultural content of the Christian message. I am arguing that the content of the Christian message, particularly its affordance for rupture, was a crucial element of the 'long conversation' between the Tswana and the missionaries. Theology was central, especially the possibility of rupture that this theology afforded.

3 As people take on Evangelical and Pentecostal beliefs and practices other elements, of course, become important and meaningful to them. But for many, the initial attraction, the reason to join this church, is to bring about some kind of rupture. In focussing on this aspect, I do not mean to devalue or dismiss the other ways that people engage with this form of Christianity.

4 While urban dwellers often desire to sever ties with extended kin and the life of the village, many are often also aware of the need to forge new exchange relations in order to provide support during hard times. Thus, in many cases, alongside the neo-Pentecostal deliverance rituals, people also engage in new neighbourhood networks of exchange. For an example of these kinds of networks among Pentecostals on the Zambian Copperbelt see Haynes 2012. 


\section{REFERENCES}

Anderson, Alan 2004. An Introduction to Pentecostalism: Global Charismatic Christianity. Cambridge: Cambridge University Press.

Bacchiddu, Giovanna 2009. Before We Were All Catholics: Changing Religion in Apiao, Southern Chile. In Aparecida Vilaça and Robin Wright (eds.). Native Christians: Modes and Effects of Christianity among Indigenous Peoples of the Americas. Farnham: Ashgate.

Barker, John 1992. Christianity in Western Melanesian Ethnography. In James Carrier (ed.). History and Tradition in Melanesian Antbropology. Berkeley: University of California Press.

Barker, John 1993. 'We Are Ekelesia': Conversion in Uiaku, Papua New Guinea. In Robert Heffner (ed.). Christian Conversion: Historical and Anthropological Perspectives on a Great Transformation. Berkeley: University of California Press.

Barker, John 2004. Between Heaven and Earth: Missionaries, Environmentalists and the Maisin. In Globalization and Culture Change in the Pacific Islands, edited by Victoria Lockwood. New Jersey: Pearson Prentice Hall.

Barker, John 2012. Secondary Conversion and the Anthropology of Christianity in Melanesia. Archives de Sciences Sociales des Religions 157: 67-87.

Bialecki, Jon 2014. After the Denominozoic: Evolution, Differentiation, Denominationalism. Current Anthropology 55 (10): S193-204.

https://doi.org/10.1086/678284.

Canessa, Andrew 2000. Contesting Hybridity: Evangelistas and Kataristas in Highland Bolivia. Journal of Latin American Studies 32(1): 115-144.

Cannell, Fenella 1999. Power and Intimacy in the Christian Philippines. Cambridge: Cambridge University Press.

Chua, Liana 2012. The Christianity of Culture: Conversion, Ethnic Citizenship and the Matter of Religion in Malaysian Borneo. New York: Palgrave Macmillan.

Comaroff, Jean, and John Comaroff 1991. Of Revelation and Revolution. Vol. 1. Christianity, Colonialism and Consciousness in South Africa. Chicago: University of Chicago Press.
Comaroff, John and Jean Comaroff 1997. Of Revelation and Revolution. Vol. 2. The Dialectics of Modernity on a South African Frontier. Chicago: University of Chicago Press.

Engelke, Matthew 2010. Past Pentecostalism: Notes on Rupture, Realignment, and Everyday Life in Pentecostal and African Independent Churches. Africa 80 (2): 177-199.

https://doi.org/10.3366/afr.2010.0201.

Freeman, Dena 2002a. Initiating Change in Highland Ethiopia: Causes and Consequences of Cultural Transformation. Cambridge: Cambridge University Press.

Freeman, Dena 2002b. From Warrior to Wife: Cultural Transformation in the Gamo Highlands of Ethiopia. Journal of the Royal Antbropological Institute 8 (1): 34-44. https://doi.org/10.1111/1467-9655.00097.

Freeman, Dena 2012a. The Pentecostal Ethic and the Spirit of Development. In Dena Freeman (ed.). Pentecostalism and Development: Churches, NGOs and Social Change in Africa. London: Palgrave Macmillan.

Freeman, Dena 2012b. Development and the Rural Entrepreneur: Pentecostals, NGOs and the Market in the Gamo Highlands, Ethiopia. In Dena Freeman (ed.). Pentecostalism and Development: Churches, NGOs and Social Change in Africa. London: Palgrave Macmillan.

Freeman, Dena 2013a. Value Chains for Development: An Ethnography of Pro-Poor Market Interventions in Ethiopia. Anthropology of This Century Issue 6. http://aotcpress.com/articles/ chains-development-ethnography-propoor-marketinterventions-ethiopia/. <accessed 29 April 2018>

Freeman, Dena 2013b. Pentecostalism in a Rural Context: Dynamics of Religion and Development in Southwest Ethiopia. PentecoStudies 12 (2): 231-249. https://doi.org/10.1558/ptcs.v12i2.231.

Freeman, Dena 2015. Cultural Techniques of Happiness: Moving Towards and Away from the Good Life in a Rural Ethiopian Community. $H A U$ : Journal of Ethnographic Theory 5 (3): 157-176. https://doi.org/10.14318/hau5.3.009.

Gibson, James 1977. The Theory of Affordances. In Robert Shaw and John Bransford (eds.). Perceiving, Acting, and Knowing: Toward an Ecological Psychology. Hillsdale, NJ: Erlbaum. 
Gibson, James 1986. The Ecological Approach to Visual Perception. New York: Lawrence Erlbaum Associates.

Gingrich, Andre and Richard Fox (eds). 2002. Anthropology, by Comparison. London: Routledge.

Gow, Peter 2006. Forgetting Conversion: The Summer Institute of Linguistics in the Piro Lived World. In Fanella Cannell (ed.). The Anthropology of Christianity. Durham: Duke University Press.

Green, Maia 1995. Why Christianity is the 'Religion of Business': Perceptions of the Church among Pogoro Catholics in Southern Tanzania. Journal of Religion in Africa 25 (1): 25-47.

https://doi.org/10.2307/1581137.

Halperin, Rhoda and Judith Olmstead 1976. To Catch a Feastgiver: Redistribution Among the Dorze of Ethiopia. Africa 46 (2):146-166.

https://doi.org/10.2307/1158758.

Hann, Chris 2007. The Anthropology of Christianity Per Se. Archives of European Sociology 48 (3): 383-410.

Hann, Chris and Hermann Goltz 2010. The Other Christianity. In Chris Hann and Hermann Goltz (eds.). Eastern Christians in Anthropological Perspective. Berkeley: University of California Press.

Haynes, Naomi 2012. Pentecostalism and the Morality of Money: Prosperity, Inequality and Religious Sociality on the Zambian Copperbelt. Journal of the Royal Anthropological Institute 18 (1): 124-139.

https://doi.org/10.1111/j.1467-9655.2011.01734.x.

Haynes, Naomi 2014. Affordances and Audiences Finding the Difference Christianity Makes. Current Anthropology 55 (S10): S357-365.

https://doi.org/10.1086/678285.

Hirsch, Eric 2008. God or Tidibe? Melanesian Christianity and the Problem of Wholes. Ethnos 73 (2): 141-162.

https://doi.org/10.1080/00141840802180330.

Humphrey, Caroline 2014. Schism, Event and Revolution: The Old Believers of Trans-Baikalia. Current Anthropology 55 (S10): S216-225.

https://doi.org/10.1086/678476.

Jackson, Jean 1995. Culture Genuine and Spurious: The Politics of Indianness in the Vaupe's, Colombia. American Ethnologist 22 (1): 3-27.
Kalb, Don 2015. Introduction: Class and the New Anthropological Holism. In James Carrier and Don Kalb (eds.). Antbropologies of Class: Power, Practice and Inequality. Cambridge: Cambridge University Press.

Keane, Webb 2013. On Spirit Writing: Materialities of Language and the Religious Work of Transduction. Journal of the Royal Anthropological Institute 19 (1): 1-17. https://doi.org/10.1111/1467-9655.12000.

Keane, Webb 2014a. Rotting Bodies: The Clash of Stances toward Materiality and Its Ethical Affordances. Current Antbropology 55 (S10): S312321. https://doi.org/10.1086/678290.

Keane, Webb 2014b. Affordances and Reflexivity in Ethical Life: An Ethnographic Stance. Anthropological Theory 14 (1): 3-26. https://doi.org/10.1177/1463499614521721.

Lester, Rebecca 2003. The Immediacy of Eternity: Time and Transformation in a Roman Catholic Convent. Religion 33 (3): 201-219. https://doi.org/10.1016/S0048-721X(03)00057-5.

Lienhardt, Godfrey 1982. The Dinka and Catholicism. In John Davis (ed.). Religious Organization and Religious Experience. Toronto: Academic Press.

Luehrmann, Sonja 2010. A Dual Quarrel of Images on the Middle Volga: Icon Veneration in the Face of Protestant and Pagan Critique. In Chris Hann and Hermann Goltz (eds.). Eastern Christians in Anthropological Perspective. Berkeley: University of California Press.

Madson, Richard 2003. Catholic Revival During the Reform Era. The China Quarterly 174: 468-487.

McDougall, Debra 2009. Christianity, Relationality and the Material Limits of Individualism: Reflections on Robbins's 'Becoming Sinners'. Asia Pacific Journal of Anthropology 10 (1): 1-19.

https://doi.org/10.1080/14442210802706855.

Meyer, Birgit 1998a. 'Make a Complete Break with the Past': Memory and Post-Colonial Modernity in Ghanaian Pentecostalist Discourse. Journal of Religion in Africa 28 (3): 316-349. https://doi.org/10.2307/1581573.

Meyer, Birgit 1998b. Commodities and the Power of Prayer: Pentecostalist Attitudes Towards 
Consumption in Contemporary Ghana. Development and Change 29 (4):751-776.

https://doi.org/10.1111/1467-7660.00098.

Meyer, Birgit 2003. Ghanaian Popular Cinema and the Magic in and of Film. In Birgit Meyer and Peter Pels (eds.). Magic and Modernity: Interfaces of Revelation and Concealment. Stanford: Stanford University Press.

Meyer, Birgit 2004. Christianity in Africa: From African Independent to Pentecostal-Charismatic Churches. Annual Review of Anthropology 33: 447474.

Mosko, Mark 2010. Partible Penitents: Dividual Personhood and Christian Practice in Melanesia and the West. Journal of the Royal Anthropological Institute 16 (2): 215-240.

https://doi.org/10.1111/j.1467-9655.2010.01618.x.

Norget, Kristin, Valentina Napolitano and Maya Mayblin 2017. The Anthropology of Catholicism: A Reader. Oakland: University of California Press.

Pype, Katrien 2012. The Making of Pentecostal Melodrama: Religion, Media and Gender in Kinshasa. Oxford: Berghahn Books.

Robbins, Joel 2003. On the Paradoxes of Global Pentecostalism and the Perils of Continuity Thinking. Religion 33 (3): 221-31.

https://doi.org/10.1016/S0048-721X(03)00055-1.

Robbins, Joel 2004a. Becoming Sinners: Christianity and Moral Torment in a Papua Nerw Guinea Society. Berkeley: University of California Press.

Robbins, Joel 2004b. The Globalisation of Pentecostal and Charismatic Christianity. Annual Review of Anthropology 33: 117-143. https:// doi.org/10.1146/annurev.anthro.32.061002.093421.

Robbins, Joel 2007. Continuity Thinking and the Problem of Christian Culture: Belief, Time and the Anthropology of Christianity. Current Anthropology 48 (1): 5-38. https://doi.org/10.1086/508690.

Robbins, Joel 2011. Crypto-Religion and the Study of Cultural Mixtures: Anthropology, Value, and the Nature of Syncretism. Journal of the American Academy of Religion 79 (2): 408-424. https://doi.org/10.1093/jaarel/lfq098.
Robbins, Joel 2012. Transcendence and the Anthropology of Christianity: Language, Change and Individualism. Suomen Antropologi: Journal of the Finnish Antbropological Society 37 (2): 5-23.

Robbins, Joel, Bambi Schieffelin and Aparecida Vilaça 2014. Evangelical Conversion and the Transformation of the Self in Amazonia and Melanesia: Christianity and the Revival of Anthropological Comparison. Comparative Studies in Society and History 56 (3): 559-590.

https://doi.org/10.1017/S0010417514000255.

Rogers, Douglas 2010. Ex Oriente Lux, Once Again. In Chris Hann and Hermann Goltz (eds.). Eastern Christians in Anthropological Perspective. Berkeley: University of California Press.

Schwarz, Carolyn and Françoise Dussart 2010. Christianity in Aboriginal Australia revisited. The Australian Journal of Anthropology 21 (1): 1-13.

Scott, Michael 2005. 'I was like Abraham': Notes on the Anthropology of Christianity from the Solomon Islands. Ethnos 7 (1): 101-125.

https://doi.org/10.1080/00141840500048565.

Stewart, Charles 1991. Demons and the Devil: Moral Imagination in Modern Greek Culture. Princeton: Princeton University Press.

Sundkler, Bengt 1976. Zulu Zion and some Swazi Zionists. Oxford: Oxford University Press.

Vilaça, Aparecida 2014. Culture and Self: The Different 'Gifts' Amerindians Receive from Catholics and Evangelicals. Current Anthropology 55 (S10): S322-332. https://doi.org/10.1086/678118.

Vilaça, Aparecida and Robin Wright 2009. Introduction. In Aparecida Vilaça and Robin Wright (eds.). Native Christians: Modes and Effects of Christianity among Indigenous Peoples of the Americas. Farnham: Ashgate.

DENA FREEMAN

DEPARTMENT OF ANTHROPOLOGY LONDON SCHOOL OF ECONOMICS AND POLITICAL SCIENCE

d.g.freeman@1se.ac.uk 